\title{
Factors Predict Employability of Graduates: Evidence in Jose Rizal Memorial State University
}

\section{Ed Neil O. Maratas}

Instructor, College of Arts and Sciences, Jose Rizal Memorial State University-Main Campus, Dapitan City, Philippines.

\section{Archer C. Campoy}

Instructor; President, JRMSUFEA, Inc., JRMSU-Main Campus, Dapitan City, Philippines.

\begin{abstract}
The goal of this research was to track graduates to their destination and employment status. The researchers used the modified survey questionnaire developed from the researchers and served as the method for data collection. Further, information was also obtained from yahoo and Facebook accounts and mobile or cellular phones. Of the 377 respondents, 288 graduates participated in the study and were drawn randomly from the master lists of 6,677 graduates of various academic programs offered from five-year spans School Year 2006 to 2010. The findings showed that the majority in their current position is casuals. It also showed that most of the respondents work in businesses or organizations related to education, wholesale and retail trade, financial intermediation, development, and public administration. Most of them, their present work is connected to the course they took at college. Programs with the highest percentage of working graduates, JRMSU ranked Engineering as the top program offered. Teacher education, on the other hand, has more employed graduates with the highest potential for full initial earnings. Finally, the profile information that best predicts the graduates' employment likelihood is gender, GPA, and licensure exam.
\end{abstract}

Keywords and Phrases: Graduate Tracer Study, Alumni Destinations, Labor Employments, Academic Performance, Employment Probability, Dapitan City, Philippines

\section{Introduction}

The most significant tool for motivating individuals for their socio-economic, political, and technical advancement in education. However, many higher institutions in the Philippines provide several clients with instruction, but most forget them as soon as they graduate and leave the atmosphere of the institution with no means of contacting them. Via long and shortterm initiatives, these institutions have been active in improving human capital. They have the responsibility to keep track of their graduates' results. Eventually, the most significant aim of education at colleges or universities is employment. Most parents send their kids to college with the expectation that their children will be able to find a stable job after graduation. In particular, this refers to Filipino parents who see the importance of college education as the most significant inheritance they can offer to their children and the most successful way to find 
a career that will help develop their children's future. However, with the current standard of education and the pressing demand of the labor force industry, parents and graduates are frustrated because some do not qualify because they lack the requisite skills and qualifications needed by the industry because of unemployment. (Mercado, 2010).

This report reiterated the Commission on Higher Education (CHED) for tracer studies to be performed in the country by graduates of state colleges and universities. Schomburg (2003) stressed that a tracer study can obtain data on the type of most employable graduates, academic experiences (competencies gained in college) that graduates find very helpful in the workplace, and the personal academic history of graduates who can assess employability. The results of tracer studies provide critical input not only on the importance of the subjects in the various courses but also on the adequacy of the skills and knowledge of the graduates they create. (Rodriquez, S. M., and Romillo, JP E., 2011).

The learning environments of higher education institutions in Zamboanga del Norte need to become aware of the framework of their course programs. As a member of higher education institutions, JRMSU displayed great assurance to the public as it underwent AACCUP, Inc. accreditation submission processes to ensure consistency and excellence in education. Also, in designing its curricula, deciding curriculum offerings, and developing faculty, this organization will hunt down graduates to be more strategic. Besides, it may also assess the efficacy or responsiveness of the degree programs completed by the graduates and classify the cluster of courses considered most useful by the graduates in their workplaces.

Over a thousand graduates are provided annually by Jose Rizal Memorial State University. These university-generated graduates help satisfy the demands of local and national industries. JRMSU needs to keep track of its graduates to continue setting goals and formulating appropriate higher education programs. It is therefore the fervent hope of the researchers that this study will contribute and improve the policies and guidelines to achieve the relevance and responsiveness of the curricular offerings of the university in compliance with the demands of education programs.

\section{Objectives of the Study}

This study aimed to collect information on jobs currently in demand and courses considered necessary for employers to meet the requirements of those jobs, recruitment rates, and others. It has also increased in response to local, national, and global demands in different workplaces to keep records of graduates to set goals and to devise appropriate programs.

Specifically, this study sought to determine the following:

1. biographical characteristics of JRMSU graduates in terms of; 1.1 Age; and

1.2 Gender.

2. academic performance of the respondents when they were still in College;

3. educational qualifications of the respondents in terms of:

3.1 Educational attainment;

3.2 Honors or awards received;

3.3 Licensure examination passed;

3.4 Number of training attended after college;

3.5 Reasons for pursuing advanced studies; and

3.6 Skills or competencies found most useful in the job.

4. employment status of respondents in terms of:

4.1 Current employment status;

4.2 Type of employment status;

4.3 Occupation; 
4.4 Job search time;

4.5 Job level position;

4.6 Initial gross monthly income;

4.7 The relevance of course to the job; and

4.8 The satisfaction of their job.

5. profile information that best predicts the employment probability of the graduates.

\section{Research Methods}

This research is primarily a survey methodology intended to track graduates to their job destination from their school of origin. The researchers used the questionnaire developed and developed by the Department of Labor and Employment to obtain the necessary data (DOLE). That served as a guide for the researchers to gather the data needed.

Via random selection, from SY 2007-2008 to SY 2011-2012, there were 377 out of 6,677 JRMSU System graduates who became the study's target respondents. Even if JRMSU offers graduate study programs, only undergraduate students were included in the analysis. In deciding the required number of target respondents, Slovin's formula was used. The study respondents were asked to carry out the survey form directly sent to them either via snail mail, email, or contact persons. The telephone or mobile phone was used to interview and check the details provided in the survey form.

To calculate the percentage of frequency of occurrence of the different categories defined in the questionnaire, the quantitative data collected via the questionnaire was subjected to a statistical test. As a statistical instrument in the study, a frequency count, percentage estimation and ranking, mean and standard deviation, and binary logistic regression analysis were used.

\section{Results and Discussions} Biographical Profile of Graduates

From SY 2006 to 2007 up to SY 2009 to 2010, there were 6,677 JRMSU System graduates. Around 377 graduates were required to trace their biographical, destination, and labor market indicators as target respondents. However, about 228 questionnaires were recovered, which indicated that the research included only 228 graduates. The instrument (questionnaire) was sent to the graduates via email and Facebook account, while some of the questionnaires were administered to them personally in some districts of Zamboanga del Norte. The questionnaires retrieved were adequate to make inferences about the graduates from 2006 to 2010.

As respondents in the sample, the biographical profile of JRMSU alumni showed that most of them were female or 56 percent between 19 and 23 years of age (54 percent). This showed that the majority of JRMSU graduates were female and between the ages of 19 to 23. The data showed that, as seen in the growing pattern of enrollment in JRMSU for several years, women were more interested in pursuing their education than their counterparts. The number of dropouts sponsored by males was therefore dominant compared to female graduates.

The study's findings were corroborated by the findings of Mercado (2010), which revealed that the majority of MSEUF graduates who participated in the study as respondents were single and female residents of Region IV, especially those residing in the province of Quezon in Lucena City.

\section{Academic Performance of Graduates}

When they were in college, the majority of graduates performed well. The data showed that some graduates were trained and knowledgeable in their respective fields at this institution. It is evident in a mean (1.94) which when they were in college falls in good results. This 
illustrated that when taking their baccalaureate degrees, they performed well. Also, the respondents struggled hard in their studies to obtain a higher grade so that their scholarship could retain the cutoff grade.

\section{Educational Qualification of the Respondents}

Table 1 shows the frequency distribution of the JRMSU alumni across the discipline. Statistics revealed that most of them were from the field of Teacher Education with (27.67\%). As observed in the entire JRMSU system, teacher education has been a flagship of this institution in terms of clients' preference over curricular offerings from School Years 2006 to 2010. Traditionally, teacher education is the affordable course program and the favorite of the many as far as this study is concerned. And perhaps this is the only organization/agency that would cater better employment in Zamboanga del Norte. Some were inherited from their family tree, majority of graduates' parents were also educators.

In the second place, graduates of Computer Studies were (19.33 percent). Tourism and HRM (11.84\%); Business and Accountancy and Criminology (10.09\%); Nursing and Allied Health Studies (8.87\%); Arts and Sciences (5.70\%); Engineering (5.70\%); (4.39 percent). Finally, Agricultural Research yielded $2.20 \%$. This implies that only a few graduates were enrolled in the fields of Arts and Sciences, Engineering and Agriculture because only a few students were enrolled in the courses offered in those fields. This is because most of the courses were challenging under the aforementioned programs, which is why the graduate cohort survival was very minimal.

Table 1 Frequency Distribution of the Respondents across the discipline

\begin{tabular}{lcc}
\hline \multicolumn{1}{c}{ Discipline } & Frequenc & Percentage \\
\hline Arts and Sciences & $\boldsymbol{y}$ & \\
Business and Accountancy & 13 & $5.70 \%$ \\
Teacher Education & $\mathbf{2 3}$ & $10.09 \%$ \\
Computer /Tech. Studies & 63 & $27.67 \%$ \\
Engineering & 44 & $19.33 \%$ \\
Criminology & 10 & $4.39 \%$ \\
Tourism and HRM & 23 & $10.09 \%$ \\
Nursing and Allied Health & $\mathbf{2 7}$ & $11.84 \%$ \\
Studies & 20 & $8.78 \%$ \\
Agricultural Studies & & \\
\multicolumn{1}{c}{ Total } & 5 & $2.20 \%$ \\
\hline
\end{tabular}

The scholastic honors earned by graduates after graduation are shown in Table 2 . Approximately 18.86 percent of respondents graduated with scholastic honors from the table, with most of them from teacher education courses. In comparison, only 12.72 percent of graduates received an award, while 0.44 percent of alumni were Magna Cum Laude recipients and 5.7 percent were Cum Laude recipients.

Table 2 Scholastic Honors Received

\begin{tabular}{ccc}
\hline $\begin{array}{c}\text { Honors or Awards } \\
\text { Received }\end{array}$ & Frequency & Percentage \\
\hline Summa Cum Laude & 0 & -- \\
Magna Cum Laude & 1 & $0.44 \%$ \\
Cum Laude & 13 & $5.7 \%$ \\
Others & 29 & $12.72 \%$ \\
\hline
\end{tabular}


Table 3 showed the passers-by in licensing exams administered by the Professional Regulation Commission (PRC) in different disciplines. Approximately 50 of the learners, or less than onefourth of the total respondents (21.9 percent), were passers-by in their fields of research. It is therefore expected that, provided that he/she is in elementary education, the likelihood of graduates passing the licensure exam is approximately 51.16 percent and 55.0 percent given that he/she is secondary education. The figure showed a 39.13 percent chance of completing the criminology graduate exams. In terms of health sciences, the Bachelor of Science in Nursing and other allied courses requiring the said test are 25.0 percent likely to pass the licensing exam. Finally, $30.0 \%$ of the chances of moving from the College of Engineering are expected to pass the licensing test.

Table 3 Licensure Examinations Passed

\begin{tabular}{ccc}
\hline PRC Examination & Frequency [n=50] & Percentage \\
\hline LET - Secondary & 11 & $4.82 \%$ \\
LET - Elementary & 22 & $9.65 \%$ \\
Criminology & 9 & $3.95 \%$ \\
Nursing & 5 & $2.19 \%$ \\
Engineering & 3 & $1.32 \%$ \\
\hline
\end{tabular}

Another method in this analysis may be considered to be training courses attended and reasons for attending and conducting advanced research. Training can be graded as; advanced studies/graduate program, short-term related training, short-term intensive professional development seminar, professional credential program, and another work-related program that may be obtained before and after graduation by graduates. Table 4 indicates that with 8.33 percent, 48.68 percent of JRMSU graduates completed training, obviously in advanced studies or graduate program. For professional advancement, their primary reason for pursuing advanced studies or graduate programs is (7.46 percent). Since most of the graduates working are teachers. This only shows that professional learning confirms a deep enthusiasm for the profession (Mercado, 2010). Furthermore, promotion is another excuse for them to take the next step on the ladder of their respective promotion. In this competitive environment, he added, a person should have a high degree of educational achievement to be promoted to the higher ranks.

Training among graduates, on the other hand, includes short-term professional-related training (7.02 percent), short-term comprehensive professional development workshops (10.09 percent), post-baccalaureate or professional qualification programs (13.6 percent), and other work-related training (9.65 percent). According to their job description, the graduates attended numerous training sessions (40.36 percent). The findings show that advanced studies and training programs are essential for graduates who are currently working and seeking a job.

The graduates thought that the advanced studies would give them more chances for their immediate promotion and a greater and lucrative reward for them. Besides, in taking advanced studies, they also considered their deep enthusiasm for the field and became role models. 
Table 4 Trainings Attended and Reasons for attending Training and Pursuing Advanced Studies after College

\begin{tabular}{|c|c|c|c|c|}
\hline \multirow[b]{2}{*}{$\begin{array}{c}\text { Trainings or Advance } \\
\text { Studies }\end{array}$} & \multicolumn{3}{|c|}{ Reasons } & \multirow[b]{2}{*}{ Total } \\
\hline & $\begin{array}{l}\text { Professional } \\
\text { Development }\end{array}$ & Promotion & $\begin{array}{l}\text { Other } \\
\text { Reason }\end{array}$ & \\
\hline $\begin{array}{l}\text { Advance Studies or } \\
\text { Graduate Program }\end{array}$ & $17(7.46 \%)$ & $2(0.88 \%)$ & - & 19(8.33\%) \\
\hline $\begin{array}{c}\text { Short Term Professional } \\
\text { Related Training }\end{array}$ & - & - & $16(7.02 \%)$ & $16(7.02 \%)$ \\
\hline $\begin{array}{c}\text { Short Term intensive } \\
\text { Professional Development } \\
\text { Seminar }\end{array}$ & - & - & $23(10.09 \%)$ & $23(10.09 \%)$ \\
\hline $\begin{array}{c}\text { Post Baccalaureate or } \\
\text { Professional Certificate } \\
\text { Program }\end{array}$ & - & - & $31(13.6 \%)$ & $31(13.6 \%)$ \\
\hline $\begin{array}{c}\text { Other Work Related } \\
\text { Training }\end{array}$ & - & - & $22(9.65 \%)$ & $22(9.65 \%)$ \\
\hline
\end{tabular}

Communication skills with 23.49 percent tended to be the skill that is considered most useful to graduates in their work, among the skills or competencies gained in graduate college. The human interaction is close (21.48 percent) and this was followed by teaching skills (16.78 percent), IT and management skills (14.77 percent). The entrepreneurship skill was what appeared in Table 5 to be the skill that was least useful to the graduates in their jobs, as only 1.34 percent of the respondents who are currently working listed it. It follows from this scenario that the business, organization, or employer would no doubt never hesitate to recruit graduates from this university once you have the qualifications and you are legibly competent. Therefore, JRMSU educators can continue to expand quality teaching to refine the various abilities or competencies of this university's clients.

Table 5 Skills or Competencies found most useful on the job

\begin{tabular}{ccc}
\hline Skills or Competencies & Frequency & Percentage \\
\hline Communication Skills & 35 & $23.49 \%$ \\
Human Relation Skills & 32 & $21.48 \%$ \\
Information Technology & 22 & $14.77 \%$ \\
Skills & 22 & \\
Management Skills & 25 & $14.77 \%$ \\
Teaching Skills & 2 & $16.78 \%$ \\
Entrepreneurship Skills & 11 & $1.34 \%$ \\
Other Skills & & $7.38 \%$ \\
\hline
\end{tabular}

Courses with the highest percentage of employed and unemployed graduates

The data shown in Table 6 shows that: Engineering; Arts and Sciences; Computer Studies; Business and Accountancy; and Criminology are the top five programs that have the highest percentage of graduates working. On the other hand, as of October 2011, the following are the top five programs with the highest number of unemployed graduates: Nursing and Allied Health Sciences, Tourism and HRM, Agricultural Studies, Teacher Education and Criminology, respectively. Given the fact that criminological research both took place on the top five working and unemployed programs, but still disposed of an enticing program given. In comparison, market demand for graduates of Nursing and Allied Health Sciences showed fewer prospects compared to other programs offered in Zamboanga del Norte's JRMSU System.

On the other hand, due to family and health problems, some explanations for the number of unemployed graduates $((30.65 \%)$ further stated that they could not compete with other 
graduates from other universities. Furthermore, most of the respondents have been fired or terminated a contract, thereby losing their work and classifying them as unemployed alumni.

Table 6 Current Employment Situation and Course Program of the Respondents

\begin{tabular}{|c|c|c|}
\hline \multirow{2}{*}{ Program } & Employed & Unemployed \\
\cline { 2 - 3 } & Frequency (\%) & Frequency (\%) \\
\hline Arts and Sciences & $10(76.92 \%)$ & $3(23.08 \%)$ \\
\hline $\begin{array}{c}\text { Business and } \\
\text { Accountancy }\end{array}$ & $17(73.91)$ & $6(26.09 \%)$ \\
\hline Teacher Education & $39(61.90 \%)$ & $24(38.10 \%)$ \\
\hline Computer Studies & $33(75.00 \%)$ & $11(25.00 \%)$ \\
\hline Engineering & $8(80.00 \%)$ & $2(20.00 \%)$ \\
\hline Criminology & $15(65.22 \%)$ & $8(34.78 \%)$ \\
\hline Tourism and HRM & $16(59.26 \%)$ & $11(40.74 \%)$ \\
\hline $\begin{array}{c}\text { Nursing and Allied } \\
\text { Health Sciences }\end{array}$ & $8(40.00 \%)$ & $12(60.00 \%)$ \\
\hline Agricultural Studies & $3(60.00 \%)$ & $2(40.00 \%)$ \\
\hline Total & $149(65.35 \%)$ & $79(34.65 \%)$ \\
\hline
\end{tabular}

\section{Employment Status of Graduates}

In Table 7, the form of current status and occupation of respondents is revealed. It appeared in the table that the majority of alumni occupations were service staff and shop and business sales employees (42.95 percent) in their status type and more casual employees (44.3 percent) in the relevant occupation. This table further explains that, with temporary to permanent status, roughly 3 or 4 out of 10 alumni (34.23 percent).In those categories, 24.16 percent of them are or are required to be 2 or 3 graduates out of 10 working graduates for five years listed as technical and in government service. Since the majority of graduates had the required skills or competencies (ranging from $1.34 \%$ to $23.49 \%$ ) for each discipline, the majority of them $(55.04 \%)$ were skilled associates in Zamboanga del Norte and even in the world.

Table 7Type of Present Status and Present Occupation of the Respondents

\begin{tabular}{|c|c|c|c|c|c|c|}
\hline \multirow[b]{2}{*}{ Occupation } & \multicolumn{5}{|c|}{ Status } & \multirow[b]{2}{*}{ Total } \\
\hline & $\begin{array}{l}\text { Regular } \\
\text { or } \\
\text { Perman } \\
\text { ent }\end{array}$ & $\begin{array}{c}\text { Temporar } \\
y\end{array}$ & $\begin{array}{c}\text { Contractu } \\
\text { al }\end{array}$ & $\begin{array}{c}\text { Self- } \\
\text { employe } \\
d\end{array}$ & Casual & \\
\hline Professionals & 24 & 4 & 8 & - & 15 & $\begin{array}{c}51(34.2 \\
3) \\
\end{array}$ \\
\hline $\begin{array}{c}\text { Officials of } \\
\text { Government and } \\
\text { Special-interest, } \\
\text { Organizations, } \\
\text { Corporate } \\
\text { Executives, } \\
\text { Managers, } \\
\text { Managing } \\
\text { Proprietors and } \\
\text { Supervisors } \\
\end{array}$ & 5 & 3 & 2 & - & 6 & $\begin{array}{c}16(10.7 \\
4)\end{array}$ \\
\hline $\begin{array}{c}\text { Technicians and } \\
\text { Associate } \\
\text { Professionals }\end{array}$ & - & 1 & 6 & 1 & 7 & $\begin{array}{c}15(10.0 \\
7)\end{array}$ \\
\hline Service Workers & & & & & & \\
\hline
\end{tabular}




\begin{tabular}{|c|c|c|c|c|c|c|}
\hline $\begin{array}{c}\text { and Shop and } \\
\text { Market Sales } \\
\text { Workers }\end{array}$ & 4 & 9 & 13 & 1 & 37 & $\begin{array}{c}64(42.9 \\
5)\end{array}$ \\
\hline $\begin{array}{c}\text { Farmers, Forestry } \\
\text { Workers and } \\
\text { Fishermen }\end{array}$ & - & 1 & - & - & 1 & $2(1.34)$ \\
\hline $\begin{array}{c}\text { Plant and Machine } \\
\text { Operators and } \\
\text { Assemblers }\end{array}$ & - & - & 1 & - & - & $1(0.67)$ \\
\hline Total & $\begin{array}{c}33(22.1 \\
5)\end{array}$ & $18(12.08)$ & $30(20.13)$ & $2(1.34)$ & $66(44.3)$ & $\begin{array}{c}149(10 \\
0\end{array}$ \\
\hline
\end{tabular}

The work quest time and place of working graduates acquired are provided in Table 8 . The outcome shows that most of the graduates working (42.28 percent) are in a high-level role that classifies the following: rank-and-file, level of supervision, and level of management. Most of the graduates employed (57.75\%) belong to other jobs, such as contractual, part-time, etc. As for the job search time spent among the graduates before landing their job, 38.93 percent of graduates were less than 6 months old; 34.9 percent of graduates were between 6 months and 1 year old; 14.77 percent of graduates were between 1 year and 2 years old; overall, 11.4 percent of graduates were looking for their job for more than 2 years. This further concluded that the longer the quest time, the lower the chances of occupying the high-ranking positions.

Since the majority (73.82\%) of the graduates landing a job one (1)a year and below, and pursued their advanced studies, thus the majority of them occupied decent jobs. However, of those who occupy the associate professional to a professional category, $42.28 \%$ of them were in a high-level position while $57.72 \%$ belongs to a low-level position.

Table 8Job Search Time and Level Position

\begin{tabular}{|c|c|c|c|c|c|}
\hline \multirow[b]{2}{*}{ Level Position } & \multicolumn{4}{|c|}{ Search Time } & \multirow[b]{2}{*}{ Total (\%) } \\
\hline & $\begin{array}{l}\text { Less than } 6 \\
\text { months }\end{array}$ & $\begin{array}{l}6 \text { months } \\
\text { to } 1 \text { year }\end{array}$ & $\begin{array}{c}1 \text { year to } 2 \\
\text { years }\end{array}$ & $\begin{array}{c}\text { More than } 2 \\
\text { years }\end{array}$ & \\
\hline Rank-and-File & 17 & 21 & 12 & 5 & $55(36.91)$ \\
\hline Supervisory level & 1 & 1 & 1 & 2 & $5(3.36)$ \\
\hline Managerial level & 1 & 2 & - & - & $3(2.01)$ \\
\hline Others & 39 & 28 & 9 & 10 & $86(57.72)$ \\
\hline Total(\%) & $58(38.93)$ & $52(34.9)$ & $22(14.77)$ & $17(11.4)$ & $149(100)$ \\
\hline
\end{tabular}

As shown in Table 9, the majority $(67.1 \%)$ of the working graduates were happy with their current employment, as nearly three-fourths of the jobs of the respondents were linked to their course. Of that amount, the graduates' probabilities were approximately 64.49 percent happy in their work, provided that these were important to their course. 16.67 percent, however, are the odds of graduates who have not been fulfilled because their career has not been connected to their course.

The main reason for the employed graduates why their course was not relevant to their job is because "There was an opening in the field which I immediately applied for" this garnered about $76.19 \%$. Only a few $(23.81$ percent) graduates whose reasons "I could not get a satisfactory job in my training area; either the pay is poor or I do not like the job available" and "My training is insufficient; I could not compete with other graduates from other colleges or universities in the same field. 
Table 9 Level of Satisfaction and Course Relatedness of Employed Graduates

\begin{tabular}{|c|c|c|c|}
\hline \multirow{2}{*}{$\begin{array}{c}\text { Level of } \\
\text { Satisfaction }\end{array}$} & Yes & No & Total \\
\cline { 2 - 4 } & & 7 & $20(13.4 \%)$ \\
\hline Not Satisfied & 13 & 31 & $100(67.1 \%)$ \\
\hline Satisfied & 69 & 4 & $29(19.5 \%)$ \\
\hline Very Satisfied & 25 & $42(28.19 \%)$ & $149(100 \%)$ \\
\hline Total & $107(71.81 \%)$ & \multicolumn{3}{|c|}{ Related to the Course } \\
\hline
\end{tabular}

Programs with the highest potentials for highest initial earnings

The highest initial income per program appeared in teacher education, computer sciences, criminology, tourism, and HRM and engineering courses, respectively, as shown in Table 10. These are probably the course programs offered with the largest number of graduates working. Approximately $23.49 \%$ (35 out of 149) graduates received the highest compensation from their respective employers. This means that in the province of Zamboanga del Norte and even in the whole nation in general, these are courses with high earnings in return after becoming employed. This showed that one of the SUCs that produced high-caliber and successful graduates in this part of the country was the Jose Rizal Memorial State University (JRMSU) System.

Table 10 Highest Initial Earnings per Program

\begin{tabular}{|c|c|c|c|c|c|c|c|}
\hline \multirow[b]{2}{*}{ Program } & \multicolumn{6}{|c|}{ Salary } & \multirow[b]{2}{*}{ Total } \\
\hline & $\begin{array}{c}\text { Below } \\
\text { P3,000 }\end{array}$ & $\begin{array}{l}\text { P3,000 to } \\
\text { below } \\
\text { P6,000 }\end{array}$ & $\begin{array}{l}\text { P6,000 to } \\
\text { below } \\
\text { P8,000 }\end{array}$ & $\begin{array}{l}\text { P8,000 to } \\
\text { below } \\
\text { P10,000 }\end{array}$ & $\begin{array}{l}P 10,000 \\
\text { to below } \\
P 12,000\end{array}$ & $\begin{array}{l}P 12,000 \\
\text { and } \\
\text { above }\end{array}$ & \\
\hline $\begin{array}{l}\text { Arts and } \\
\text { Sciences }\end{array}$ & 2 & 3 & 2 & 2 & 1 & - & $10(6.71)$ \\
\hline $\begin{array}{l}\text { Business and } \\
\text { Accountancy }\end{array}$ & 1 & 4 & 8 & 3 & 1 & - & $17(11.41)$ \\
\hline $\begin{array}{c}\text { Teacher } \\
\text { Education }\end{array}$ & 4 & 7 & 4 & 5 & 2 & 17 & $39(26.17)$ \\
\hline $\begin{array}{l}\text { Computer } \\
\text { Studies }\end{array}$ & 2 & 10 & 7 & 5 & 3 & 6 & $33(22.15)$ \\
\hline Engineering & 1 & - & 1 & 3 & 2 & 1 & $8(5.37)$ \\
\hline Criminology & - & 5 & 1 & - & - & 9 & $15(10.07)$ \\
\hline $\begin{array}{c}\text { Tourism and } \\
\text { HRM }\end{array}$ & 2 & 8 & 1 & 2 & 1 & 2 & $16(10.74)$ \\
\hline $\begin{array}{l}\text { Nursing and } \\
\text { Allied Health } \\
\text { Sciences }\end{array}$ & - & 7 & 1 & - & - & - & $8(5.37)$ \\
\hline $\begin{array}{c}\text { Agricultural } \\
\text { Studies }\end{array}$ & 1 & - & 2 & - & - & - & $3(2.01)$ \\
\hline Total & $13(8.72)$ & $44(29.53)$ & $27(18.12)$ & $20(13.42)$ & $10(6.71)$ & $35(23.49)$ & 149 \\
\hline
\end{tabular}

\section{Profile information that best predicts the employability of the graduates}

To assess which of the profile information better predicts the employability of the graduates, Binary Logistic Regression analysis was used. Gender, age, year, licensing exam, GPA, and honors earned were predictor factors. A majority of respondents (65.4 percent) earn their work total percentage excluding the predictor model. Moreover, relative to the unemployed, the estimated chances of graduate-respondents being working are 1.886 times.

Omnibus Tests of Model Coefficients incorporated the predictor variables, giving a Chi-Square value of 43.622 with 13 degrees of freedom, which is highly important beyond 5 percent and 1 
percent of error tolerance. This is a test of the null hypothesis that the ability to predict the choices made has not been substantially improved by introducing the predictor variables to the model. Also, the Hosmer-Lemeshow test gives a Chi-Square value of 7.253 with 8 degrees of freedom, 5 percent of which is not significant. A non-significant outcome implies that the knowledge matches the model. This implies that the predictor variables and the log odds of the criterion variable have no linear relationship (employment status).

The model was able to correctly identify $(135 / 149)=90.6$ percent of the graduates who were employed and $(30 / 79)=37.97$ percent of those who were not employed, based on the classification table performance, for an overall success rate of 72.4 percent.

For each of the predictors, Table 11 indicates the binary logistic regression coefficient, Wald measure, and odds ratio([Exp(B)]. Predictor variables having substantial partial effects with 0.05 criterion of statistical significance are gender, GPA, and licensure test. The odds ratio for gender shows that a female graduate is 0.385 times less likely to secure the job than her counterpart while keeping all other variables constant. On the other hand, relative to those graduates without licenses, license graduates are 0.395 times less likely to get their work. Although these graduates had greater chances of good to very good results, they were 55.021 times more likely to be employed than those with bad performance.

In summary, the model leads to the estimate that the likelihood of female working graduates is $[0.1077 / 1.1077]=9.72$ percent and $[0.1104 / 1.1104]=9.94$ percent, of licensed graduates .

Table 11 Binary Logistic Regression Predicting Employment from Predictor Variables

\begin{tabular}{|c|c|c|c|c|c|c|c|}
\hline \multicolumn{2}{|c|}{ Variables } & B & S.E. & Wald & $\mathrm{df}$ & Sig. & $\operatorname{Exp}(B)$ \\
\hline \multirow[t]{17}{*}{ Step $1^{\mathrm{a}}$} & Age & .011 & .076 & .021 & 1 & .885 & 1.011 \\
\hline & Gender(1) & -.954 & .345 & 7.635 & 1 & .006 & .385 \\
\hline & YEAR & & & 9.319 & 4 & .054 & \\
\hline & YEAR(1) & .200 & .635 & .099 & 1 & .753 & 1.221 \\
\hline & YEAR(2) & 1.457 & .726 & 4.026 & 1 & .045 & 4.291 \\
\hline & YEAR(3) & -.621 & .466 & 1.775 & 1 & .183 & .538 \\
\hline & YEAR(4) & .492 & .418 & 1.387 & 1 & .239 & 1.636 \\
\hline & GPA & & & 15.534 & 3 & .001 & \\
\hline & GPA(1) & 4.008 & 1.341 & 8.927 & 1 & .003 & 55.021 \\
\hline & GPA(2) & 3.124 & 1.151 & 7.364 & 1 & .007 & 22.743 \\
\hline & GPA(3) & 2.136 & 1.137 & 3.529 & 1 & .060 & 8.468 \\
\hline & Honors & & & .055 & 3 & .997 & \\
\hline & Honors(1) & .045 & .480 & .009 & 1 & .925 & 1.046 \\
\hline & Honors(2) & 18.827 & 40192.970 & .000 & 1 & 1.000 & $1.502 \mathrm{E} 8$ \\
\hline & Honors(3) & -.227 & 1.255 & .033 & 1 & .856 & .797 \\
\hline & $\begin{array}{l}\text { LicensureE } \\
\text { Xam(1) }\end{array}$ & -.930 & .401 & 5.363 & 1 & .021 & .395 \\
\hline & Constant & -1.274 & 2.241 & .323 & 1 & .570 & .280 \\
\hline
\end{tabular}

a. Variable(s) entered on step 1: age, gender, YEAR, GPA, Honors, licensure exam.

\section{Conclusions}

The following conclusions are drawn based on the study's results. A majority of Jose Rizal Memorial State University graduates were women aged 19 to 23 years of age with good standing results. More than a fifth of the participants came from the field of teacher training. Although at least a fraction of the alumni earned scholastic awards during their college tenure, 
several graduates failed the Professional Regulation Commission's licensing exam. After graduation, the majority of the graduates attended advanced studies or graduate program preparation, not so much for promotion but professional development. Also, they find communication and human relationship skills very beneficial in their current work. Concerning the respondents' employed condition, most of them were employed, although some are unemployed due to certain factors, such as family and health problems, for example, and that they did not find a job after graduation. In their current job as either a professional or as clerks, those who were hired were mainly in casual status. Most of them, their present work is connected to the courses they took in college and have a degree of satisfaction. Most of them had less than six months of work in their job hunt. Some graduates have an initial gross monthly income of Php3,000 and below Php6,000, and few of them have been employed as professionals and in positions of supervision or management. Several graduates have an initial gross monthly income of Php3,000 and below Php6,000, and few of them have been employed as professionals and in positions of supervision or management. Arts and sciences, business and accountancy, computer studies, engineering, and criminology were the top five programs with the highest number of graduates working. Teacher Education, Computer Sciences, Engineering, Criminology and Tourism, and Hotel and Restaurant Management were the top five programs with the greatest potential for the highest initial earnings. Sex, general point average and licensing examination are among the profile details that best predict the employability of the graduates. Strong output and passed the board test, which in turn requires less time to land a job.

\section{Recommendations}

Based on the significance of the data obtained and suggestions provided by the graduates, the following recommendations were made. On a college-wide basis, the Graduate Tracer Analysis (GTS) should be carried out annually by JRMSU System researchers. To update teachers and enhance their teaching skills, the administration should include faculty development programs; upgrade the facilities; review and update the university's curriculum and syllabi; add more major subjects that require practical deliverables, and reduce the class size of students to 35 or less. The JRMSU administration should monitor and facilitate partnership programs between the CHED, industry sectors, and the academe about training, OJT, practicum, and curriculum revisions to address the perceived problems of obsolete programs.

\section{Declaration of Interest}

The authors declare that they have no known competing financial interests or personal relationships that could have appeared to influence the work reported in this paper.

\section{References}

[1]. Boaduo, et.al. (2009). Tracer Study as a Paradigm for the Enhancement of Quality Course Programmes Development in Higher Education Institution in South Africa. Educational Colloquium at University of the North - West, Potchefstroom Campus, South Africa.

[2]. Cosser,M. (2003). Technical College Responsiveness: Learner Destinations and Labour Market Environments in South Africa, Cape Town, HSRC Publisher.

[3]. Lalican, N. (2007), Tracer Survey of Agriculture Graduates, 10 th National Congress on Statistics, EDSA Shangri-La Hotel October 1-2, 2007

[4]. Largoza, G. (2003). Open/Distance Learning and the Changing Labour Market: Toward a Framework for Rethinking Educational Governance Structures. PASCN Discussion paper No. $2003-02$

[5]. Mercado, F. (2010).A Tracer Study of MSEUF Graduates, MSEUF Research Studies Journal Volume XII no. 1

[6]. Rodriguez, S. (2006). University of the East Graduate Tracer Study (School Year 2000-2001 to School Year 2003-2004). Manila: University of the East. 
[7]. Schomburg, H. (2003). Handbook for Graduate Tracer Studies, Center for Research on Higher Education and Work University of Kassel, Moenchebergstrasse17, 34109 Kassel, Germany. Kassel, Germany

[8]. Retrieve Feb. 15, 2011. http://www.qtafi.de/handbook_v2.pdf

Retrieve Feb. 24, 2011. http://cscresearch.wordpress.com/2007/06/01/ched-commissions-cscto-conduct-graduate-tracer-study/

[9]. Retrieve Feb. 15, 2011. CHED commissions CSC to conduct Graduate Tracer Study: Catanduanes State Colleges Research Services.mht June 12007. 